DOI: 10.30519/ahtr.599199

Advances in Hospitality and Tourism Research (AHTR)

\title{
CAPTURING MUSEUM EXPERIENCE WITH EMOTIONAL TRANSFER THEORY
}

\author{
Onur SELCUK ${ }^{1}$ \\ Faculty of Tourism, Akdeniz University, Antalya, Turkey \\ ORCID: 0000-0003-2818-2291 \\ Meryem AKOGLAN KOZAK \\ Faculty of Business, Anadolu University, Eskisehir, Turkey \\ ORCID: 0000-0003-0577-1843
}

\begin{abstract}
In contemporary museology, visitor relations have become increasingly important. This has led museums to adopt a visitororiented approach. Although many aspects of visitor experiences are investigated in the literature, it is observed that emotional experiences are not explained in a comprehensive way. This study aims to discover the emotions that the artefacts in museums located in Eskisehir, Turkey arouse at the visitors. Initially, the museum websites were scanned and information about museums was obtained. Then, nine museums, which included artefacts in their collection that can transfer emotions with a specific theme, were chosen. Semi-structured interviews were carried out with 127 participants who visited the chosen museums. The interviews
\end{abstract}

\section{Article History}

Received 31 July 2019

Revised 3 February 2020

Accepted 4 February 2020

\section{Keywords}

thematic museums

emotional transference

visitors

Eskisehir

Turkey

\footnotetext{
${ }^{1}$ Address correspondence to Onur Selcuk, Akdeniz University, Faculty of Tourism, Antalya, TURKEY.

E-mail: onurselcuk@akdeniz.edu.tr
} 


\section{INTRODUCTION}

Societies have had valuable artistic artefacts reflecting their cultures throughout history. As a venue, the idea of the museum began in the late Middle Ages. The objectives of museums have changed over time to reflect shifts in society. Initially, while museums were used for research and education, they became places representing nationalism as a result of the reforms in societies (Erbay, 2011). As a result of postmodern and contemporary influences, modern museums must produce exhibits as well as manage social responsibilities (Demir, 2013). While these changes occur in museums over time, the culture of a society exists with artefacts that represent traditions. What happened after the Industrial Revolution also affected museums (Madran, 1999). There has been a change in the role of the visitor, in terms of museology, as a result of the widespread use of leisure and holiday concepts and the value of people as consumers. With the understanding of contemporary museology, museums are now becoming organizations that take into consideration the wishes and expectations of visitors (Demir, 2013). The efforts to increase visits have strengthened marketing and business activities in museums (Sandell \& Janes, 2007). Considering the effects of museums on visitors and interest in increasing visitors' number, it is evident rise in research studies aimed at investigating visitor experiences (Duncan \& Wallach, 1980).

The traditional collection, conservation, research and display functions of contemporary museums have been expanded. The changes have led museums to communicate with visitors rather than develop collections, not only with large masses but also with specific target groups and individual visitors (Demir, 2013). In the 1990s, the view that museums were not only collections, but also important actors, gained prevalence (Onur, 2012, p. 32). When the scientific studies on visitors are examined, there is a large number of work related to the quality of service in this field (Yücelt, 2000; Nowacki, 2005; Mylonakis \& Kendristakis, 2006; Mey \& Mohamed 2009; Doğan \& Karakuş, 2014; Yilmaz, 2011; Umur, 2015), visitor satisfaction (Brida et al., 2013; Trihn \& Ryan, 2013; Oral \& Çelik Yetim, 2014), and museum experience (Dierking \& Falk, 1992; Falk, 2009; Chan \& Yeoh, 2010; Dirsehan, 2011). With the proliferation of museum types, it is seen that museums that are subject to cultural tourism are affected by other alternative types of tourism. The museums, which include dark tourism, diaspora tourism, sad tourism and similar, have started to reflect the characteristic features of these tourism types to its visitors. In visitor research, traces of this development can be seen (Allan \& Altal, 2016; Geiling \& Ong, 2016; Çetinsöz, 2017; Kaygusuz, 2017). 
Studies about visitor experiences mainly focus on the quality of service, visitor motivation and expectations. However, considering that most museums are composed of artefacts with artistic value, it can be said that current visitor experience studies should be handled from the perspective of art history and art philosophy. In museology, it is necessary to question what the visitor's feelings about artefacts and museums are. Emotions can affect the experiences of visitors, but reveal the nature of the artefacts in museums as well. In addition, considering that the most of museum collections are composed of valuable artefacts, it can be said that the emotions of these artefacts conveyed to visitors are also important. Finally, it is also emphasized that museum managers and curators should provide clues to the artefacts, leading to the development of new exhibition designs.

As a result, the phenomenon of "emotion" has been the subject of research in many different disciplines. In tourism literature, the concept of emotion is often the subject of research in the context of the customer (Filep \& Deery, 2010; Gountas et al., 2011; Mura \& Khoo-Lattimore, 2012) and staff (Hochschild, 1983; A ğca \& Ertan, 2008; Carnicelli-Filho, 2013; Türker, 2016). However, researches on the emotions arising from the artefacts in museum remain insufficient. Based on the reasons mentioned, current study aims to discover the emotions that the artefacts in museums arouse among the visitors. In this context, the emotional transfer theory (ETT) is determined to be an important basis and the research is constructed within the framework of this theory.

For the purpose of this study, the importance and necessity of the concept of emotion in the artefacts is outlined first. After that, a detailed description of the emotional transference theory developed by L. N. Tolstoy (2004) is provided. In this study, ETT was chosen to provide the basis for the interview questions to explain the feelings of museum visitors. The findings of the study reveal the visitors' emotions created by the exhibitions. In addition, the suggestions presented in the conclusion section provide guidance on how to improve the emotional transfer to visitors of the museums.

\section{EMOTIONAL TRANSFERENCE THEORY AND ITS ANTECEDENTS}

The emotional transference theory was developed by Russian philosopher and writer L. N. Tolstoy in the 19th century. Tolstoy discussed his thoughts about the theory in his book, What Is Art? (Tolstoy, 2004). The art 
approaches and ideas that existed during Tolstoy's life affected the development of his theory. These include mimesis, romanticism, expressionism theories and these assume the basic dimensions for his theory.

Mimesis refers to imitation and is based on the notion that art is a copy. Viewing art as a reflection has occurred for centuries and continues in our time (Moran, 1999, p. 17). According to Tolstoy (2004, p. 121), emulation is not a measure of the excellence of art because the main characteristic of art is the passing of the artist's feelings to others. By the 1790s, the romanticism movement formed and remained important until the 1850s. In England, romanticism began in the artefacts of poets such as William Blake, Lord Byron, Percy Shelley, Robert Burns, William Wordsworth, Samuel Taylor Coleridge, John Keats. It continued in the artefacts of musicians such as Wolfgang Amadeus Mozart, Joseph Haydn, Ludwig van Beethoven, Johann Wolfgang Goethe and Friedrich Schiller in Germany (Barrett, 2008, p. 59). On the other hand, philosophers such as Johan Fichte, Friedrich Schelling, Arthur Schopenhauer, Friedrich Nietzsche rejected the experimental (realistic) philosophy and produced new ideas on artistic creation and artist sentiment (Barrett, 2008, p. 59). In the following century, art philosophers such as Benedetto Croce and R. G. Collingwood explained the definition of art as the act of creating (Moran, 1999). They argued that the expression of emotions must be realized for creation to occur (Graham, 2005, p. 119). On the other hand, according to Tolstoy, art is the environment of relations that unites people around the same emotions; art is an activity based on the perception of one's feelings by seeing or feeling the feelings of someone (Tolstoy, 2004, p. 51).

The most important difference between ETT and romanticism and expressionism are that, according to ETT, artwork creates a connection between the artist and the audience through emotions. Therefore, Tolstoy believed that forming emotions in the inner world of the artist or the expression to the emotions is not enough. Tolstoy holds the audiences at the centre of the theory (Weitz, 1956). From the perspective of ETT, if there is a transfer of emotion, the effects of the art are "intensity of transference", "prevalence" and "nature of emotions".

\section{Intensity of transference}

For ETT, the most decisive feature that distinguishes real art from imitations is its ability to transfer emotion. If the audience feels the emotions and the mood of the artist and this connection occurs for other people, then an art 
action is counted (Tolstoy, 2004, p. 168). The stronger the emotional infectiousness, the more successful it is as an artwork. Transference is the most important requirement for art. Without this, the work is not an artwork, no matter how realistic it is (Moran, 1999, p. 121). The occurrence of the transference depends on three criteria: "individuality", "clarity" and "sincerity" (Ross, 1994, p. 180).

If an artist conveys his own feelings to his work, it means these feelings are original (Benitez, 2012). The more personal the feeling is, the more strongly it affects the audience (Tolstoy, 2004, p. 169). Benitez (2012) states that the clearness criterion is probably the closest link between Tolstoy's three criteria about the severity of transference. If a feeling is conveyed clearly, it can spread to large audiences. The clearer the transference of emotion, the more effective it is because the audience connected to the artist is satisfied with the emotions they feel (Tolstoy, 2004, p. 169). Tolstoy emphasizes that sincerity is the most important among the three criteria and the most influential. The artwork should primarily affect its creator, implying that the mood of the artist is immediately transmitted to those that feel a connection with the artwork (Moran, 1999, p. 121).

\section{Prevalence}

In Tolstoy's theory, prevalence is reflected in the thoughts of "art for art" and "society for art" that creates great controversy during its existence. Tolstoy is one of those who thought art should exist for society and that art must reflect social reality because it is a part of social life (Tezcan, 2011, p. 45). No artist, according to those who defend the concept of art for society, creates work for him/herself. On the contrary, he/she expects his/her work to be seen, read and listened to by others (Soykan, 2009, p. 13). The value patterns that exist in society always begin in social interaction. Therefore, it is not possible to clarify the issue without applying society to the nature of art and the artist (Ulusoy, 2005, p. 13). Tolstoy advocates that society has an important role as an audience in the nascency of emotional transference. The amount that the artwork appeals to the masses and the more it is understood, defines whether the piece qualifies as a true work of art or not (Tolstoy, 2004, p.83).

\section{Nature of emotions}

In order to determine what is considered valuable among the artefacts, the nature of the emotion is also considered. The feelings that art conveys are separated into two categories: "universal feelings" that everyone can share 
and "religious feelings" arising from religious consciousness (Moran, 1999, p. 124; Trivedi, 2004, p. 43).

There are universal emotions that every society can feel (Ortony \& Turner, 1990, p. 316). Plutchik (1980) described the universal emotions that motivate people's adaptive behaviour in his "Emotion Wheel" model: joy, trust, fear, surprise, sadness, disgust, anger, and anticipation. He states that the eight basic emotions consist of opposite poles: four positive emotions and four negative emotions. These can form complex emotions when combined. With joy and anticipation come optimism, trust and fear come together to create submission, surprise and sadness causes disapproval, anger and disgust creates contempt, joy and trust come together to create love, anticipation and anger derive aggressiveness, fear and surprise induce awe, and lastly, sadness and disgust lead to remorse (Plutchik, 1980; 2001).

Tolstoy argues that the feelings conveyed can also contain the feelings arising from religious consciousness. Some art critics consider this to be reactionary (Matthews, 1979; Leddy, 1987; Wertz, 1998), while others advocate his view (Casey, 1971; Daniels, 1974; Jahn, 1975; Long, 1998). Tolstoy states that every society has a religious consciousness of its time and that this sense is the most sublime one for a specific society. This type of emotion is reflected in the artefacts that are valuable for society (Tolstoy, 2004, p. 56).

\section{RESEARCH METHOD}

When the factors such as overcrowding of museum visits during the day, lack of an emotion scale prepared by quantitative approach to emotional transfer theory, and the thought that the emotional experience issue in this study is more prone to qualitative research approach are considered, it is understandable the researcher's choice to adopt qualitative approach in the current study. The interview technique was used to assess the emotional experiences of museum visitors. According to Patton (1987), the aim of the interview is to enter an individual's inner world and understand his perspective. For this purpose, a semi-structured interview form was created with contributions from the literature review.

The nine interview questions were submitted to nine experts who are academicians in Tourism (four people), Art History (three people) and Fine Arts (two people). The process of obtaining expert opinions was carried out in two stages. Initially, the experts evaluated questions in terms of 
expression, content and punctuation. With the feedback obtained, the interview questions were revised for a second time and put into the final form. As a result of the evaluations of art history and fine arts experts, the seventh question, "What do you want to say about the views that art is for art and/or art is for society?" was removed from the interview form. After the interview form was finalized, a "question-answer key" was created to guide the research process. The question-answer key was used in the content analysis of the interview texts. The finalized interview questions are as follows:

1. What do you think about the artefacts in the museum in general?

2. How did the artefacts in the museum make you feel in terms of emotion?

3. Do the artefacts in the museum adequately describe the emotions you feel? Can you explain it briefly?

4. Did the artefacts give you special feelings on your museum visit? Can you tell us about your feelings?

5. Were the feelings you felt during your museum visit clear and apparent?

6. To what extent do the artefacts you see during your museum visit show the sincerity and feelings of the artist?

7. Did the artefacts arouse some basic feelings in you? For example, feeling of astonishment, or sadness or cheerfulness against some artefacts?

8. Did the artefacts arouse religious feelings in you during your museum visit?

\section{Study Setting}

In the first stage, 19 museums in the centre of Eskisehir, Turkey were considered in the scope of the study. To determine which museums would comprise the final study site, a document/website analysis was conducted. For this purpose, web pages of museums with current information were examined. Web page review is a method that is widely used today thanks to the development of internet technologies. An observation form was created for the systematic review of web pages. The observation form was created with the help of an expert, and it includes information about the genre of the museum. After a document analysis, some museums that did not have artistic elements in their exhibitions were excluded.

Museums that were classified as art museums and themed museums (Demiral Gökalp, 2015, p. 76) were determined to meet the aim of the ETT (Weitz, 1956; Wertz, 1998; Tolstoy, 2004, p. 51). Therefore, the "Woodworks 
Museum", the "Contemporary Glass Arts Museum", the "Contemporary Arts Museum", the "Education Cartoons Museum", the "Eti Archaeology Museum", the "Liberation Museum", the "Meerschaum Museum", the "Eskisehir City Memory Museum" and the "Yilmaz Buyukersen Wax Sculptures Museum" were selected for the study site.

\section{Data collection process}

Prior to collecting data, official permission was obtained from the "Eskisehir Odunpazari Municipality" and "Eskisehir Provincial Directorate of Culture and Tourism" to which the museums are affiliated. In-person interviews were conducted in the five-month period between December 2017 and April 2018. In the interviews, written notes were taken as well as audio recordings. Semi-structured interviews were carried out with 127 participants who visited the chosen museums. The participants were selected by convenience sampling, owing to uncertainty of number of visitors. The interviews lasted from 5 to 30 minutes. When the interviews reached enough saturation, the raw data were transcribed and prepared for the analysis process. The content analysis technique was used in the data analysis. The main objective of content analysis is to determine the concepts and relationships that can explain the collected data (Yıldırım \& Şimşek, 2016). While interview texts were subjected to content analysis, the question-answer key previously prepared by the researcher was used. Meanwhile, a computer package program (Nvivo 10) was used to perform content analysis.

\section{FINDINGS AND EVALUATION}

In the study, the findings were obtained by evaluating the main themes of ETT (Basic Dimensions, Intensity of Transference and Nature of Emotions). The explanations also contain quotations from the participant's views. Participant names are coded for the purposes of confidentiality.

\section{Findings on the "Basic Dimensions" theme}

Mimesis, romanticism and expressionism approaches have been effective in the development of Tolstoy's theory of art. From this point of view, "antimimesis", "romanticism" and "expressionism" were the basic dimensions and evaluated as the main themes (Table 1). 
Table 1. Reference Distribution of Basic Dimensions

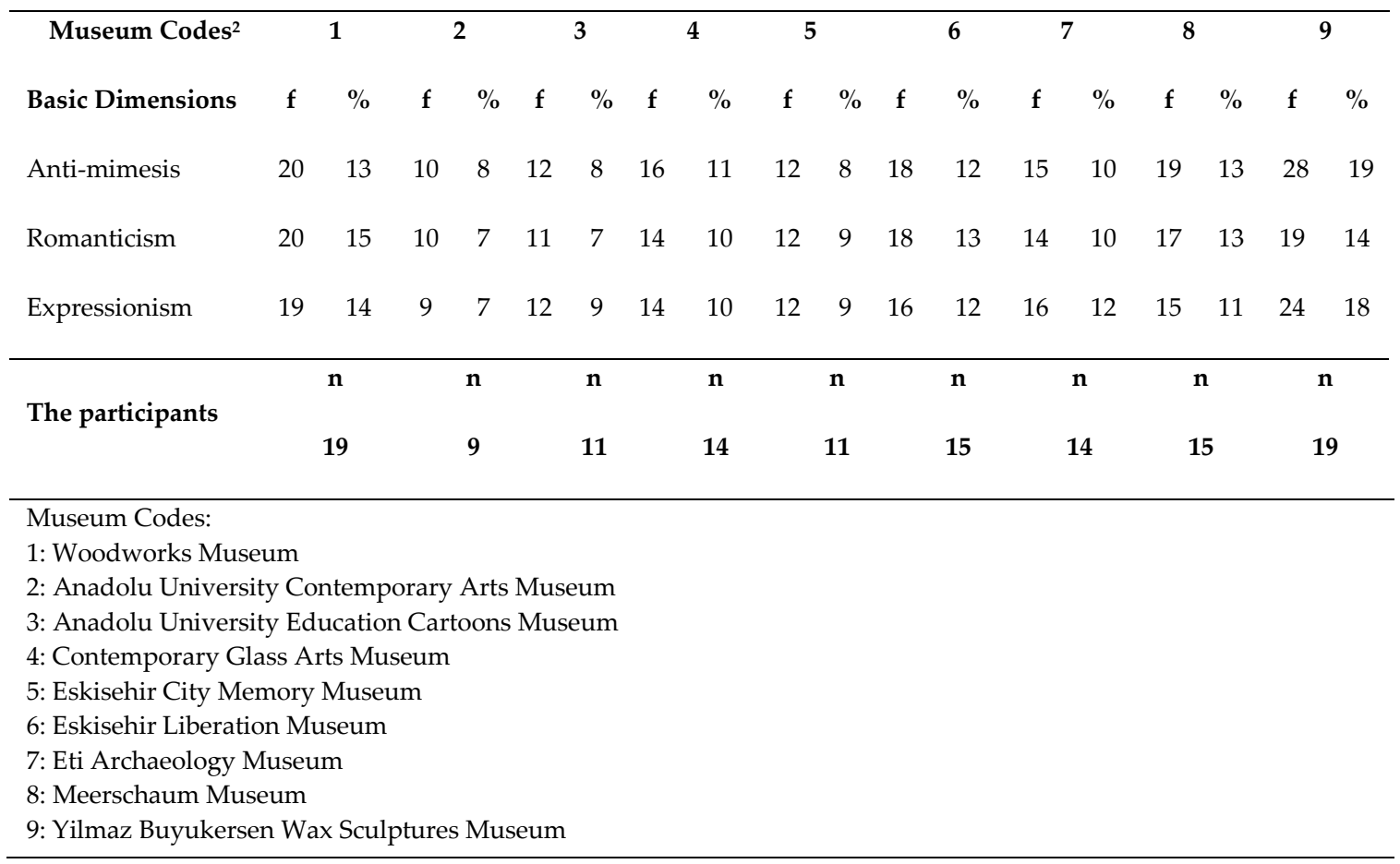

The sub-themes related to the theme of anti-mimesis are "Positive or negative evaluation of artistic, aesthetic, historical and archaeological values" and "Real/copy artefacts awareness". The frequency distribution indicates that museums have left positive impressions on visitors. Therefore, the exhibits have artistic, aesthetic, historical and archaeological value. In particular, the intensive expression transfer emerging in the wax museum (10 references in 28) can be interpreted as the art and aesthetic aspects of wax statues. However, it must be considered that these statements may be made as a result of the fact that the statues do not resemble the original. In other museums, the participants made evaluations by reviewing the artefacts and the creativity, labour qualities and form of structures rather than concentrating on whether it was real or replicated. Some statements about the theme from the participants are:

"When I look at their work, I think it is a museum that reflects people who had something to do with this country, without being good or bad. It certainly does nor express any particular opinion but a general view." (Wax Museum-P3)

"I like that octopus. Creating something like this from the root of the tree is not what everyone can do." (Woodworks Museum-P15)

${ }^{2}$ The same museum codes are used in each table. 
"I think that cartoons describe situations that need to be told in daily life but cannot be expressed. For this reason, this museum is successful in explaining both our society and the problems around the world." (Cartoons Museum-P1)

"There is no work in the museum. It was like the introduction of Eskisehir. I couldn't see a museum or any work. There were a few pieces in the last parts, a few pieces made of wood and glass, but I think the pieces were placed in there for the sake of the work." (City Memory Museum-P4)

In the theme of romanticism, the emotional status of visitors is explained with the sub-themes of "Reflecting the artist's feelings and emotions on the audience" and "Non-sensations of the audience". When the frequency distributions shown in Table 1 were examined, the main theme of romanticism was referenced the most in the Woodworks Museum (20 references). The subsequent ranking is the Wax Museum (19 references), the Liberation Museum (18 references) and the Meerschaum Museum (17 references). Most visitors (75\%) stated that they were influenced by the artefact in the museums, that the artist conveyed their feelings to the artefacts and that these feelings affected them. In the museums that contain abstract artefacts of art in its collection, the participants experienced more emotional transfer than in other museums. It can be assumed that the reason for the high artistic value of these artefacts and the attractiveness to their audiences is that they reflect the creativity and imagination of the artist. The participants in the Contemporary Glass Arts and the Contemporary Arts Museum had emotionally different experiences. It was observed that they were more touched by the artefacts in which they knew the story, or the artist, or when they could interpret some meaning on their own. On the other hand, in the City Memory Museum some participants (25\%) were unable to get an impression from the exhibitions and had different perspectives in accepting them as artefacts. For example, participants perceived the work as virtual and digital. In the Meerschaum Museum, the participants did not find the artefacts as original due to the lack of exhibitions, presentations and guided explanations. However, in general discourse, the audience felt that the work reflected the artist's feeling and emotion. Some participant views to support the findings are:

"In some of the artefacts in the museum, I can say that I have some feelings in terms of the artist's imagination, talent, and labour. When I examined the artefacts, I was able to see the labour and the feeling that the artist wanted to convey in many artefacts." (Glass Arts Museum-P13)

"Frankly, when I saw those artefacts, I suddenly made a journey to history and saw how these items were used, and this excited me." (Archaeology Museum-P9) 
"In general, the feeling created by the artists reflects itself in all of the artefacts they make. Besides, they are all capable of expressing themselves without any explanation. (Woodworks Museum -P11)

"It was not a feeling that I was impressed. There was more of an interest." (Meerschaum Museum-P12)

"There was not much emotional stuff because they were publicity videos." (City Memory Museum-P4)

When evaluating participant statements for the expressionism theme, "Reflects the emotion that it wants to give", "No emotion is reflected" and "Instructional" sub-themes were created. From the frequency distributions in Table 1, it was observed that the main theme of expressionism is mostly referenced in the Wax Museum (24 references). The second museum is the Woodworks Museum (19 references). The general opinion of the participants for the theme of expressionism is that they perceive the emotional expression performed by the artists in the artefacts they examine with a rate of $67 \%$. The general characteristics of museums providing expressionism are that they include original artefacts made by qualified artists and that the visual and audio presentations of the artefacts are well done. The participants were able to feel more emotional expressions in the museums that carry these characteristics. The artefacts in the Cartoon Museum and the Contemporary Arts Museum were able to provide emotional arousal thanks to the subjects which were used by the artist. However, participants who did not spend much time in the museum or who were not interested in the artefacts stated that these did not contain a narrative but only visual appeal. Such a transfer is clearly indicated in the museum of Meerschaum. Some of the participants who visited the museum argue that the artefacts did not exhibit any emotion. Perhaps this can be explained not by the lack of artistic value, but by the fact that the artefacts are limited to standard-looking or very few different motifs. Another noteworthy finding is that some participants (7\%) stated that the artefacts were instructive even if they did not find emotional expression in them. In particular, the Archaeology Museum and the Liberation Museum, which contain historical and archaeological artefacts in their collections, have been historically instructive and informative for the visitors. With a general explanation, the expression of the emotions of the exhibitions is reflected in the emotions of the participants:

"It depends on what you went to the museum for. So, you may not feel any emotion if you have just gone for a walk. But if you try to understand the underlying 
meaning of cartoons, then you can feel the emotion. That's what happened to me." (Cartoon Museum-P1)

"When we look at it, the artefacts in this collection are the artefacts that are reflecting characteristic of that artist. Then yes, the names here are the artefacts that will give the character of those artists and their ideas." (Contemporary Arts Museum-P2)

"The visuals, voices, and animations that were presented there addressed our perception as much as possible. " (Liberation Museum-P2)

"For example, they could have left their inspiration as a small note. They just wrote who did it, but they could write what they told (about this artefact)." (Woodworks Museum-P3)

"If I give an example about the museum, there was no official explanation of the history, how it was founded and how it was processed. We couldn't get a lot of information about them. Yes, I'm visiting, but only visually. It's just visually nice, yes, but it's actually not a very efficient visit." (Meerschaum Museum-P1)

"It has helped us to learn about all periods from past to present. We learned the lifestyle. The artefacts were informative." (Archaeology Museum-P12)

\section{Findings on the "Intensity of Transference" theme}

While the transfer of emotions is important for an art activity, the determinant of whether it is considered a good artwork is the intensity of transference. According to Tolstoy, the intensity of transference depends on three criteria: "individuality", "clarity" and "sincerity". The findings of the main themes and sub-themes are listed in Table 2.

Table 2. Reference Distribution of Intensity of Transference

\begin{tabular}{|c|c|c|c|c|c|c|c|c|c|c|c|c|c|c|c|c|c|c|}
\hline Museum Codes & \multicolumn{2}{|c|}{1} & \multicolumn{2}{|c|}{2} & \multicolumn{2}{|c|}{3} & \multicolumn{2}{|c|}{4} & \multicolumn{2}{|c|}{5} & \multicolumn{2}{|c|}{6} & \multicolumn{2}{|c|}{7} & \multicolumn{2}{|c|}{8} & \multicolumn{2}{|c|}{9} \\
\hline $\begin{array}{l}\text { Intensity of } \\
\text { Transference }\end{array}$ & f & $\%$ & f & $\%$ & f & $\%$ & f & $\%$ & f & $\%$ & f & $\%$ & f & $\%$ & f & $\%$ & f & $\%$ \\
\hline Individuality & 16 & 12 & 9 & 7 & 11 & 9 & 14 & 11 & 12 & 9 & 15 & 12 & 14 & 11 & 16 & 12 & 21 & 16 \\
\hline Clarity & 23 & 16 & 14 & 10 & 15 & 10 & 13 & 9 & 11 & 8 & 14 & 10 & 14 & 10 & 19 & 13 & 20 & 14 \\
\hline Sincerity & 22 & 15 & 12 & 8 & 13 & 9 & 16 & 11 & 13 & 9 & 16 & 11 & 14 & 10 & 19 & 13 & 21 & 14 \\
\hline \multirow{2}{*}{ The participants } & \multicolumn{2}{|c|}{$\mathbf{n}$} & \multicolumn{2}{|c|}{$\mathbf{n}$} & \multicolumn{2}{|c|}{$\mathbf{n}$} & \multicolumn{2}{|c|}{$\mathbf{n}$} & \multicolumn{2}{|c|}{$\mathbf{n}$} & \multicolumn{2}{|c|}{$\mathbf{n}$} & \multicolumn{2}{|c|}{$\mathbf{n}$} & \multicolumn{2}{|c|}{$\mathbf{n}$} & \multicolumn{2}{|c|}{$\mathbf{n}$} \\
\hline & \multicolumn{2}{|c|}{19} & \multicolumn{2}{|c|}{9} & \multicolumn{2}{|c|}{11} & \multicolumn{2}{|c|}{14} & \multicolumn{2}{|c|}{11} & \multicolumn{2}{|c|}{15} & \multicolumn{2}{|c|}{14} & \multicolumn{2}{|c|}{15} & \multicolumn{2}{|c|}{19} \\
\hline
\end{tabular}


The theme of individuality is explained in the study by two different sub-themes: "feeling individual emotions" and "creating ordinary feelings". According to the frequency distributions in Table 2, The Wax Museum (21 references), the Woodworks Museum (16 references) and the Meerschaum Museum (16 references) have the most comments about having individual artefacts. The museum with the least statements is the Contemporary Arts Museum ( 9 references). The participants agreed with the theme of feeling individual emotions with a rate of $59 \%$. From this point of view, it can be said that the exhibitions in the museums are perceived as moderately unique for visitors. In museums with visual artefacts in its collection, the artefacts are perceived to be the original. The participants find the tangible artefacts that they can objectively see. Exhibitions in the Wax Museum or the Liberation Museum are examples of this case. Negative perceptions of abstract video artefacts in the City Memory Museum also support this situation because some of the participants did not evaluate the video artefacts as original piece of art. The museum, which has the least original artefacts, is the Meerschaum Museum. Some participants' views on the theme of originality are:

"There is a room in the museum describing the war of liberation. When we entered the room, we sat in the sandbags. The feeling of sitting in the trenches gave me a bit of emotion." (Liberation Museum-P3)

"The people who are worth to remember like Kemal Sunal, Barış Manço, Aşık Veysel made me feel special." (Wax Museum P-11)

I mean, it doesn't appeal to me. It doesn't make sense to me." (Meerschaum Museum-P5)

"No. I haven't had any special feelings." (City Memory Museum-P8)

The clarity criteria are explained by the sub-themes of "being complicated", "being intelligible" and "feeling the emotion clearly", as it is evaluated in relation to the clarity of the transmitted emotions. When the frequency values are examined, it was observed that the most interpreted museums are the Woodworks Museum (23 references), the Wax Museum (20 references) and the Meerschaum Museum (19 references). The emotions conveyed by the artefacts are closely related to the emotional bond that the audience has established with the work. If the participants can understand the artefacts, they can feel the emotions reflected by the work. When subthemes are evaluated, participants found that the artefacts are understood and convey the feeling clearly. In other words, the participants evaluated a work as open if it was understandable. The Liberation Museum, the Archaeology Museum, and the Wax Museum are examples of these 
experiences. Participants stated that emotions are complex in the Woodworks Museum, the Contemporary Arts Museum, and the Meerschaum Museum because of the inclusion of abstract artefacts in their collections. Eventually, the artefacts convey clear and understandable feelings to $66 \%$ of the participants. In this context, it can be said that the artefacts in the museums are clear and intelligible enough to be understood by a wide audience. Some of the participants' views on the sub-themes are:

"A little bit, some work is complex, of course, there must be some intellectual knowledge to capture the same feeling of thought. I personally have difficulty understanding the surrealist artefacts." (Woodworks Museum-P14)

"Inadequate, there is a relief sculpture, but I don't know what it belongs to. The interest does not pass to me." (Meerschaum Museum-P6)

"Critical works on social issues were especially clear and understandable." (Cartoon Museum-P10)

"Yes, I had feelings of patriotism throughout the museum trip. In every section I have seen, these feelings have continued to increase. It was clear and understandable." (Liberation Museum-P7)

According to the participant statements, the sincerity criteria was explained by the sub-themes of "artefacts reflect sincerity", "the work is not sincere" and "finding something of yourself". Regarding the reference distributions in Table 2, the artefacts with the most comments were found in the Woodworks Museum (22 references), the Wax Museum Sculptures (21 references) and the Meerschaum Museum (19 references). The participant comments indicate that the artefacts reflect the sincerity of the artist to a great extent (63\%). The artefacts exhibited in the Liberation Museum (94\%), the Wax Museum (76\%) and the Contemporary Arts Museum (75\%) were found to be the sincerest. It can be said that the artefacts whose story is known or appealing to all segments of society are sincerer. The Liberation Museum and the Wax Museum contain such artefacts. However, since the Contemporary Glass Arts Museum, the Woodworks Museum and the Contemporary Arts Museum were not found to be understandable by most participants, the sincerity of the artist was not mentioned very positively. Sincerity can be thought of as a phenomenon formed by the artist's own will. However, in cases where the artist is asked to produce a subject that does not require creativity, he becomes unable to benefit from his own sincerity and creativity. An example of this case is the video artefacts in the City Memory Museum. The visitors state that they have learned historical information about certain subjects from these artefacts, but they do not feel any sincerity from the artist. The exhibition 
opportunities of the artefacts also affected the sincerity. For instance, souvenir shops and sales activities in the Meerschaum Museum negatively affected emotional transference. Many indigenous Meerschaum artefacts have been commercial commodities. In addition, some participants felt spontaneous sincerity from the artefacts created by an unknown artist. The Woodworks Museum and the Contemporary Glass Arts Museum are examples of this situation. The participants felt sincerity between the artefacts and themselves without needing to know the feelings of the artist. As a result, the sincerity of the artefacts was accepted by the visitors with a significant rate $(63 \%)$, although it varied according to the type of work, the recognition of the artist, the story of the creation and the venue of the exhibition.

"The artefacts were very successful. The talent of the artist was hidden in every detail of his artefacts... It was clear that the artist was doing the work by revealing all his sincerity and feelings." (Wax Museum- P11)

"In some artefacts, it is very difficult to derive emotions and thoughts from abstract artefacts, but each work already leaks information about its artist in every way." (Contemporary Arts Museum - P5)

"If we're talking about this place, I don't think so, it's a little more commercial. I was expecting bigger place when the museum was called, but the shops were obviously not. It's called a museum, but there are shops inside. Sales are a priority, rather than reflecting something." (Meerschaum Museum-P1)

"If you're talking about City memory, you need to make sure that foreigners who live or come to that City have that connection. It must be sincere and the participants in the video need to reflect this sincerity somehow. There is no good video editing. There is a chain of videos shot with a single camera, sometimes supported by some images. So, I think it's weak in terms of cinema and video. There's mould. In all the videos, it is the matter that you can see the same pattern. I didn't see much creativity there. I have not seen sincerity." (City Memory Museum- P11)

\section{Findings on the "Nature of Emotions" theme}

In the nature of emotions, the kind of emotions that are felt during the transfer is evaluated. In theory, the emotions that an artwork can convey are either "universal emotions" or "religious emotions". Universal feelings can be understood by all segments of society. These can be simple and understandable basic emotions or emotions that are a combination of a few basic emotions. From this point of view, universal feelings in the study were discussed as two sub-themes: "basic emotions" and "combined emotions". 
Plutchik (1980) also supports Tolstoy's notion of universal feelings. Plutchik (1980) considers the basic emotions to be joy, trust, fear, surprise, sadness, disgust, anger, and anticipation. In this context, the participant statements were analysed, and the findings related to the basic emotions are presented in Table 3.

Table 3. Reference Distribution of Nature of Emotions

\begin{tabular}{|c|c|c|c|c|c|c|c|c|c|c|c|c|c|c|c|c|c|c|}
\hline Museum Codes & \multicolumn{2}{|c|}{1} & \multicolumn{2}{|c|}{2} & \multicolumn{2}{|c|}{3} & \multicolumn{2}{|c|}{4} & \multicolumn{2}{|c|}{5} & \multicolumn{2}{|c|}{6} & \multicolumn{2}{|c|}{7} & \multicolumn{2}{|c|}{8} & \multicolumn{2}{|c|}{9} \\
\hline $\begin{array}{l}\text { Nature of } \\
\text { Emotions }\end{array}$ & $\mathbf{f}$ & $\%$ & f & $\%$ & f & $\%$ & f & $\%$ & f & $\%$ & f & $\%$ & $\mathbf{f}$ & $\%$ & $\mathbf{f}$ & $\%$ & $f$ & $\%$ \\
\hline Universal emotions & 23 & 12 & 16 & 9 & 21 & 11 & 21 & 11 & 13 & 7 & 24 & 13 & 23 & 12 & 15 & 8 & 35 & 19 \\
\hline Basic emotions & 18 & 12 & 9 & 6 & 18 & 12 & 17 & 12 & 8 & 6 & 21 & 15 & 16 & 11 & 12 & 8 & 25 & 17 \\
\hline Combined emotions & 5 & 12 & 7 & 17 & 3 & 7 & 4 & 10 & 5 & 12 & 3 & 7 & 7 & 17 & 3 & 7 & 10 & 24 \\
\hline Religious emotions & 23 & 17 & 11 & 8 & 11 & 8 & 15 & 11 & 11 & 8 & 16 & 12 & 14 & 10 & 16 & 12 & 20 & 15 \\
\hline \multirow{2}{*}{ The participants } & \multicolumn{2}{|c|}{$\mathbf{n}$} & \multicolumn{2}{|c|}{$\mathbf{n}$} & \multicolumn{2}{|c|}{$\mathbf{n}$} & \multicolumn{2}{|c|}{$\mathbf{n}$} & \multicolumn{2}{|c|}{$\mathbf{n}$} & \multicolumn{2}{|c|}{$\mathbf{n}$} & \multicolumn{2}{|c|}{$\mathbf{n}$} & \multicolumn{2}{|c|}{$\mathbf{n}$} & \multicolumn{2}{|c|}{$n$} \\
\hline & \multicolumn{2}{|c|}{19} & \multicolumn{2}{|c|}{9} & \multicolumn{2}{|c|}{11} & \multicolumn{2}{|c|}{14} & \multicolumn{2}{|c|}{11} & \multicolumn{2}{|c|}{15} & \multicolumn{2}{|c|}{14} & \multicolumn{2}{|c|}{15} & \multicolumn{2}{|c|}{19} \\
\hline
\end{tabular}

The feelings of surprise, sadness and joy have been felt more in the basic emotions. While 52 expressions of surprise were referenced, 40 expressions were conveyed for the feeling of sadness. For joy, there were 28 expressions. The Contemporary Glass Arts Museum is the most cited museum for the sense of surprise. The participants expressed the feeling of surprise with 15 times. To generate feelings of surprise, the artefacts needed to demonstrate that the artist used different techniques, used combinations of many different colours, and gave the glass unusual shapes. For the feeling of sadness, the participants mostly commented in the Liberation Museum and Wax Museum. Eleven expressions were stated for both museums. Viewing artefacts that reminded visitors of important issues in history caused participants to be sad. When the theme of joy is examined, the participants made the most references to the Cartoon Museum (7 references). Cartoons are artefacts that can cheer people up. Therefore, some of the participants were feeling cheerful and having fun while others expressed their deep thoughts. Some of the interpretations of basic emotions are:

"I'm surprised how beautiful artefacts can emerge from a simple substance. I was astonished. As I said, they made so many interesting shapes from the glass that I 
couldn't stop thinking about how they did it."(Contemporary Glass Arts Museum-P6)

"Some of the artefacts were the people sculpture and when I read their lives, the artefacts made me feel sadness and joy." (Wax Museum- P15)

"While visiting the artefacts, it was generally fun and joyful. Since it is a cartoon museum, we laughed and had fun with most of the artefacts we looked at." (Cartoon Museum- P10)

"The artefacts based on freedom made me sad. War-themed cartoons made me sad, especially with children." (Cartoon Museum - P1)

Anger, fear and disgust are the basic emotions that were least felt during the museum trips. In terms of interpretations where feelings of anger and disgust were felt, this was due to the theme and content reflected by the artist. However, it can be said that the artefacts that created fear or disgust were the ones that reflected the creativity and imagination of the artist more clearly. Some of the artefacts in the Woodworks museum or the Contemporary Glass Arts Museum are examples of this.

"It made me feel that there might be something inside the artist's inner world, and I thought there might be anger towards the world because it seemed ugly to me. It was disgusting." (Woodworks Museum- P6)

It is possible to reach the conclusion that emotions such as fear, disgust and anger, which may be more related to the inner world of the artist, are felt more clearly in artefacts. Moreover, the findings explained above regarding basic emotions support this conclusion. The common factor of the artefacts that reflected joy, surprise and sadness are that the subjects they convey are known to the masses. Therefore, the reason that the work triggers a sad emotion may not be the emotions conveyed by the artist. The theme of the museum and the event or personality in which the work is concerned play a greater role in affecting visitors. On the other hand, it can be said that the artefacts in which emotions such as fear, disgust and anger are processed reflect the inner world of the artist in a sincerer way.

Optimism, submission, disapproval, contempt, love, aggressiveness, awe and remorse are the sub-themes of the combined emotions that occur through mixing of more than one basic emotion. The exhibition spaces in the museums, the emotions of the participants and the artistic qualities of the artefacts are effective in forming combined emotions. In addition, the participants experienced intense feelings of excitement, loneliness and disappointment. The museums where the sensation of excitement was felt 
most clearly were the Archaeology Museum and the Contemporary Glass Arts Museum. The feeling in the glass museum shows itself as an excitement due to different shapes, forms and artistic styles of the artefacts. It was observed that the feeling of longing was reflected in different artefacts, sometimes for people and sometimes for a certain time or event. For example, the participants at the Wax Museum felt a longing for the real people represented by the statues. Disappointment was felt at the Wax Museum (2 references) and the Meerschaum Museum (2 references). In the Wax Museum, the participants were disappointed since the artefacts do not look real. The statements of the participants that reflect combined emotions are:

"The artefacts they did with the technology of their time excited me." (Archaeology Museum-P5)

"Some artefacts are very exciting. When I look at the colours, I find some colours much closer to myself. It excites me, I can say that it actually gives a feeling of excitement." (Contemporary Glass Arts Museum-P1)

"Even though I do not know the past, there have been artefacts that arouse a historical longing." (Wax Museum-P8)

"My mood changed a bit because some of the artefacts narrate old times. I've been thinking about the old ones, and that's a little emotional." (City Memory Museum-P7)

"...those who are not alike are disappointing." (Wax Museum-P2)

The transference of religious emotions may vary depending on the subject and the religious view of the artist. Therefore, the theme of religious feelings is explained by three sub-themes; "religious beliefs", "not religious beliefs" and "religious messages". It was questioned whether the participant emotions were related to religious beliefs and the relationship between the work and religious beliefs. According to the frequency distribution in Table, $3,68 \%$ of references noted that the artefacts were not related to religious beliefs compared to 93 of references that expressed the artefacts did reflect religious beliefs. The most prominent museums reflecting feelings that the artefacts were not related to religious beliefs were the City Memory Museum, the Cartoon Museum, and the Archaeology Museum. However, due to the theme of some museums, the artefacts contain religious messages. An example of this is expressed by 12 references, mostly from the Woodworks Museum. While universal emotions are expressed in a total of 186 references, reflecting religious emotions is expressed in only 16 references. Based on the observations, it is very rare for the artefacts to 
convey religious feelings. The artefacts are more about education, culture, history, economy and human rights that concern society in different ways. Other issues affecting the expression of religious feelings were the location and physical characteristics of the museum. The fact that the Woodworks Museum and the Meerschaum Museum are in the Kursunlu Complex (an old mosque) can be cited as an example.

"I don't have any religious feelings. Eskisehir is a very cosmopolitan city in this sense. And I don't look at it from that perspective. It didn't make me feel any religious things." (City Memory Museum- P11)

"No, no religious issue was addressed. I didn't think so because I didn't see this." (Cartoon Museum-P4)

"There was nothing to trigger my religious feelings. It was not designed for that purpose either." (Archaeology Museum-P4)

"I have not seen much religious-themed artwork except for examples that resemble Buddhist beliefs." (Woodworks Museum-P15)

\section{CONCLUSION}

The goal of this study was to explore how the artefacts exhibited in museums compose the emotional transference to visitors. To accomplish this aim, the emotional transfer theory was adopted as the main framework in the current study. The findings were first evaluated in the context of antimimesis, romanticism and expressionism themes. On the theme of anticounterfeiting, the participants were questioned on their awareness as to whether the artefacts were real or replicated. As a result, awareness of the artefacts as real or replicated was not found in the museums, except the Wax Museum and the Meerschaum Museum. It is thought that this situation varies according to the theme of the museums and whether the collections that do not contain real artefacts are more prominent. Regarding the theme of romanticism, artists convey their feelings through the work. It is noted that museums that contain abstract artefacts in their collection were more sentimental than the other museums. The visitors stated that these artefacts had high artistic qualities and reflected the creativity of the artist better than other artefacts. Therefore, the exhibitions attracted the attention of the audience and were able to generate emotions in them. The Contemporary Glass Arts Museum and the Contemporary Art Museum emerged in this theme. Lastly, on the theme of expressionism, it was evaluated whether the artefacts that contain certain emotions illustrate these feelings to the 
audience or not. It has been observed that the artefacts provide an acceptable level of emotional expression throughout the museums. The common aspect of the museums that stand out in this theme is that they use contemporary exhibition methods well and exhibit real and original artefacts. It has been seen that museums with these qualities have generated more emotional expressiveness in their visitors.

In the second phase, the intensity of emotions conveyed in the artefacts was evaluated in terms of individuality, clarity and sincerity. Regarding individuality, it was revealed that the participants evaluated the tangible artefacts that they could see and make sense of objectively. In the case of clarity, if the work could be understood, it is expressed clearly and plainly. Regarding sincerity, it has been determined that this condition varies according to the type of work exhibited, the artist's experiences in the field, and the level of visitor's awareness of the story that is the subject of the work. Consequently, the artefacts in the Liberation Museum and the Wax Museum were found to be sincerer than in other museums. The fact that the artefacts in museums have provided three conditions that determine the intensity of emotional transference indicates that the artefacts are more artistic and valuable. As such, individuality was accepted by $59 \%$, clarity by $66 \%$ and sincerity by $63 \%$. Therefore, the artefacts in the museums provided enough transfer of emotions.

Finally, the existence of universal feelings and religious feelings in the artefacts was assessed. The most basic emotions, surprise, sadness and joy, were felt within the universal emotions. However, it has been determined that the formation of these emotions may be the result of external factors along with the artist's feelings. Another important result is that although the feelings of fear, anger and disgust were felt less often, the artefacts containing these emotions were considered to reflect the sincerity of the artist better. With such artefacts, the participants felt more connected to the artist. It is thought that the reason the combined emotions were felt less often is a result of the scarcity of the artefacts that reflect combined emotions, the feeling of different emotions from each work, the spontaneous emotional changes of the participants and different experiences according to the themes of museums. Hence, excitement, longing, and disappointment were felt as united emotions. It is concluded that religious emotions do not exist effectively in the artefacts, that the audience did not feel such emotions often and that the artists created their work with different concerns than religious beliefs. However, it is emphasized in the theory that both types of emotions are important for society's understanding of art and that religious thought will give direction 
to society on many issues. Nevertheless, religious emotions remained weak in the museums. The artefacts convey the emotions that are more relevant to society such as education, culture, history, economics, geography and human rights. The reflection of universal emotions enables the artefacts to be transferred to wider audiences. In addition, providing the conditions of clarity and individuality in the intensity of the transference and the feeling of the basic emotions in universal emotions is the result of supporting each other. Moreover, most artefacts in which combined emotions were reflected were complex and difficult to understand. As a result, in general, it can be concluded that artefacts in museums provide a transfer of emotion to the visitor, except for the anti-mimesis and religious emotions.

The previous studies dealing with the visitor experience in the existing museum and tourism literature (Dierking \& Falk, 1992; Falk, 2009; Chan \& Yeoh, 2010; Dirsehan, 2011; Alelis et al., 2013; Allan \& Altal, 2016; Geiling \& Ong, 2016; Çetinsöz, 2017; Kaygusuz, 2017; Kılıçarslan \& Caber, 2018) evaluate the experience with other subjects or discipline. For instance, they try to explain the visitor's experience with the subjects like atmosphere, and physical facilities of a museum, new technologies or with disciplines like marketing, aesthetic, education. Moreover, since the artefacts are in the foreground to the museum experience in terms of visitors, there is a lack of studies focusing on the relationship between artwork itself and visitors in the existing museum experience literature. The main contribution of this study is to explore the visitor's feelings about artefacts and their emotional transferences. This theoretical contribution of the research, thanks to the results obtained, provides beneficial information about the museum experience from the perspective of art history and art philosophy.

The results of the study lead to certain practical implications. Firstly, the most insufficient perception in terms of emotional transfer among the nine museums was found in the City Memory Museum and the Meerschaum Museum. Most of the artefacts in the City Memory museum are digital video artefacts and the use of a different display technique may have been more effective. In order to improve this situation, museum managers may be advised to use a different audio presentation technique of video artefacts. Secondly, in the Meerschaum Museum, the collection consists of unique and valuable artefacts of Eskisehir. However, the presence of souvenir sales in the museum has led to the perception of the artefacts as commercial objects. Therefore, it may be suggested that the interior of the museum is reorganized, providing more space to the Meerschaum artefacts and that souvenirs are sold outside of the museum. 
Lastly, the contents of the collections vary according to the theme and purpose of the museums. Museum management and curators decide how the artefacts will be exhibited. In the study, the collections have been highly influential in the emotional transference of the artefacts in museums. The way the collections were exhibited influenced some participants to experience complex and meaningful emotions. Thus, the current study may also be a guide to curators to consider the issue of emotion transfer when editing artefacts.

There are certain limitations to this study. As a study site, it solely focused on the museums located in the city centre. If different study areas are chosen, the results of further research may be different. Another limitation of the study is that emotions were assessed according to the museum themes. In other words, the study, in general, focused on exploring the emotional experiences of participants. Thus, the demographic information of the participants such as age, sex, marital status, etc, were not included in the research process. As a direction to future research, it is suggested to examine the role of demographic variables on emotional transference. In the data collection, the interview technique was chosen in order to get in-depth information about the nature of the participants' emotional experiences and their understanding of art. On the other hand, according to the findings, the insight of art and level of knowledge of the participants quite affect the experience. It may be suggested to future researchers to conduct the studies by controlling or manipulating these factors in order to achieve more obvious results via mixed research approaches. Moreover, the emotional formation of different presentations which concern the art field, such as cinema, theatre, or opera may differ between each other. Therefore, further research can explore these study sites as well.

\section{REFERENCES}

Ağca, V., \& Ertan, H. (2008). Duygusal bağlılık içsel motivasyon ilişkisi: Antalya'da beş yıldızlı otellerde bir inceleme [Emotional commitment -intrinsic motivation relationship: A review of five-star hotels in Antalya]. Afyon Kocatepe Üniversitesi I.I. B.F. Dergisi, 2, 135-156.

Alelis, G., Bobrowicz, A., \& Ang, C. S. (2013). Exhibiting emotion: Capturing visitors' emotional responses to museum artefacts. In International Conference of Design, User Experience, and Usability (pp. 429-438). Springer, Berlin, Heidelberg.

Allan, M., \& Altal, Y. (2016). Museums and tourism: Visitors motivations and emotional involvement. Mediterranean Archaeology and Archaeometry, 16(3), 43-50.

Barrett, T. (2008). Why Is That Art? Aesthetic and Criticism of Contemporary Art. New York: Oxford University Press. 
Benitez, E. (2012). Tolstoy and the importance of aesthetic feeling. Literature and Aesthetics, 15(2), 167-176.

Brida, J. G., Disegna, M., \& Scuderi, R. (2013). The behaviour of repeat visitors to museums: Review and empirical findings. Quality and Quantity, 48, 2817-2840.

Carnicelli-Filho, S. (2013). The emotional life of adventure guides. Annals of Tourism Research, 43, 192-209.

Casey, E. S. (1971). Expression and communication in art. The Journal of Aesthetics and Art Criticism, 30(2), 197-207.

Chan, J. K. L., \& Yeoh, E. (2010). The experiential dimensions of museum experiences: The Visitors' perspectives. International Journal of Business and Accountancy, 1(1), 20-31.

Çetinsöz, C. (2017). Karanlık (dark) Alanları ziyaret eden yerli turistleri motive eden etmenler: Ankara Ulucanlar Cezaevi Müzesine yönelik bir içerik analizi. [Factors motivating native tourists visiting dark areas: A content analysis for Ankara Ulucanlar Prison Museum], Alanya II. Uluslararası Sosyal Bilimler Sempozyumu, 1820 May 2017.

Daniels, C. B. (1974). Tolstoy and Corrupt Art. Journal of Aesthetic Education, 8(4), 41-49.

Demir, Z. S. (2013). Halk bilimi müzeciliğinde deneysel yaklaşımlar: Yaşayan müze [Experimental approaches in folklore museology: Living museum]. Turkish Studies -International Periodical for the Languages, Literature and History of Turkish or Turkic, 8(9), 1111-1125.

Demiral Gökalp, Z. (2015). Müze Türleri, [Museum Types]. In E. Altınsapan \& N. Küçükhasköylü (Eds.), Müzecilik ve Sergileme (pp.73-83). Ankara: Anadolu Üniversitesi Yayınları.

Dierking, L. D., \& Falk, J. H. (1992). Redefining the museum experience: the interactive experience model. Visitor Studies, 4(1), 173-176.

Dirsehan, T. (2011). "Romantic Movement in Marketing": The Effects of Customer Experiences on Post Experience Dimensions from the Museum Perspective. Unpublished master's thesis, Marmara University, İstanbul, Turkey.

Doğan, N. Ö., \& Karakuş, N. (2014). KFG-AHP bütünleşik yöntemi kullanılarak turizm sektöründe hizmet kalitesinin değerlendirilmesi: Göreme Açık Hava Müzesi üzerine bir uygulama [Evaluation of service quality in tourism sector using KFGAHP Integrated Method: An investigation on Göreme Open Air Museum]. Süleyman Demirel Üniversitesi İktisadi ve İdari Bilimler Fakültesi Dergisi, 19(3), 169194.

Duncan, C., \& Wallach, A. (1980). The universal survey museum. Ariel, 137, 212-199.

Erbay, M. (2011). Müzelerde Sergileme ve Sunum Tekniklerinin Planlanması [Planning and Presentation Techniques in Museums]. İstanbul: BetaYayıncılık.

Falk, J. H. (2009). Identity and Museum Visitors Experience. Walnut Creek, CA; Left Coast Press.

Filep, S., \& Deery, M. (2010). Towards a picture of tourists' happiness. Tourism Analysis, 15, 399-410.

Geiling, J., \& Ong, C. (2016). Warfare tourism experiences and national identity: The case of Airborne Museum 'Hartenstein' in Oosterbeek, the Netherlands. Tourism Management, 57, 45-55.

Gountas, S., Mavondo, F., Ewing, M., \& Gountas, J. (2011). Exploring the effects of perceived service provider sincerity on consumers' emotional state and satisfaction during service consumption. Tourism Analysis, 6, 393-403. 
Graham, G. (2005). Expressivizm Croce and Collingwood. In B. Gaut \& D. M. Lopes (Eds.), The Routledge Companion to Aesthetics (pp.119-130). London and New York: Routledge Taylor and Francis Group.

Hochschild, A. (1983). The Managed Hearth: Commercialization of Human Feeling. Berkeley: University of California Press.

Jahn, G. R. (1975). The aesthetic theory of Leo Tolstoy's what is art?. Journal of Aesthetics and Art Criticism, 34(1), 59-65.

Kaygusuz, B. (2017). Eskisehir Kurtuluş Müzesini ziyaret eden ziyaretçilerin hüzün turizmi deneyimleri [Dark tourism experiences of visitors of the Liberation Museum of Eskisehir]. In Proceedings of the 18. National Tourism Congress, pp. 925-934. Ankara: Detay Yayıncilık.

Kılıçarslan, D., \& Caber, M. (2018). The impacts of perceived crowding, and atmospherics on visitor satisfaction at cultural heritage sites: A comparison of Turkish and British visitors to Topkapi Palace, Istanbul. Journal of Tourism and Services, 9(17), 118.

Leddy, T. (1987). Rigid designation in defining art. The Journal of Aesthetics and Art Criticism, 45(3), 263-272.

Long, T. R. (1998). A selective defence of Tolstoy's what is art?. Philosophical Writings, 8, 1525.

Madran, B. (1999). Müze Türleri [Museum Types]. In T. Atagök (Ed.) Yeniden Müzeciliği Düşünmek (pp. 3-19). İstanbul: Yıldız Teknik Üniversitesi Basım-Yayın Merkezi.

Matthews, R. (1979). Traditional aesthetics defended. Journal of Aesthetics and Art Criticism, 38 (1), 39-50.

Mey, L. P., \& Mohamed, B. (2009). Measuring service quality, visitor satisfaction and behavioral intentions of museums in Malaysia. Journal of Tourism,10(2), 45-66.

Moran, B. (1999). Edebiyat Kuramları ve Eleştiri [Literary Theories and Criticism]. İstanbul: İletişim Yayıncilık.

Mura, P., \& Khoo-Lattimore, C. (2012). Young tourists, gender and fear on holiday. Current Issues in Tourism, 15(8), 707-724.

Mylonakis, J., \& Kendristakis, E. (2006). Evaluation of museums service quality: A research study of museums and galleries visitors' satisfaction. Tourism and Hospitality Management, 12(2), 37-54.

Nowacki, M. M. (2005). Evaluating a museum as a tourist product using the SERVQUAL method. Museum Management and Curatorship, 20, 235-250.

Onur, B. (2012). Çağdaş Müze Eğitim ve Gelişim Müze Psikolojisine Giriş [Contemporary Museum Education and Development Introduction to Museum Psychology]. Ankara: İmge Kitabevi Yayınları.

Oral, S., \& ÇelikYetim, A. (2014). Deneyimsel değer, tüketici tatmini ve tüketici sadakati arasındaki ilişkinin belirlenmesine yönelik bir araştırma [A research on determining the relationship between experiential value, consumer satisfaction and consumer loyalty]. Dokuz Eylül Üniversitesi Sosyal Bilimler Enstitüsü Dergisi,16(3), 469-497.

Ortony, A., \& Turner, T. J. (1990). What's basic about basic emotions?. Psychological Review, 97(3), 315-331.

Patton, Q. M. (1987). How to use qualitative methods in evaluation. London: Sage Pub.

Plutchik, R. (1980). A general psycho evolutionary theory of emotion. In R. Plutchik \& H. Kellerman (Eds.). Emotion: Theory, research and experience (pp. 3-31). New York: Academic Press.

Plutchik, R. (2001). The nature of emotions. American Scientist, 89(4), 344-350. 
Ross, S. D. (1994). Art and its significance an anthology of aesthetic theory. Albany: State University of New York Press.

Sandell, R., \& Janes, R. R. (2007). Museum management and marketing. Routledge.

Soykan, Ö. N. (2009). Sanat Sosyolojisi Kuram ve Uygulama [Sociology of Art Theory and Practice]. İstanbul: Dönence Yayınları.

Tezcan, M. (2011). Sanat Sosyolojisi Giriş [Introduction to Sociology of Art]. Ankara: Anı Yayıncilik.

Tolstoy, L. N. (2004). What is Art? (A. B. Dural, Trans.). İstanbul: Bilge Karınca Yayınları. (Original work published 1897)

Trihn, T. T., \& Ryan, C. (2013). Museums, exhibits and visitor satisfaction: A study of the Cham Museum, Danang, Vietnam. Journal of Tourism and Cultural Change, 11(4), 239-263.

Trivedi, S. (2004). Artist-audience communication: Tolstoy reclaimed. The Journal of Aesthetic Education, 38(2), 38-52.

Türker, A. (2016). Duygusal beceri değerlendirme sürecinin müşteri memnuniyetine etkisi: Turist rehberleri üzerine bir uygulama [The effect of emotional skill assessment process on customer satisfaction: An Investigation on tourist guides]. Journal of Travel and Hospitality Management, 13(2), 6-20.

Ulusoy, M. D. (2005). Sanatın Sosyal Sinırları [Social Boundaries of Art]. Ankara: Ütopya Yayınevi.

Umur, M. (2015). Turist rehberlerinin müze hizmet kalitesi algilamaları üzerine bir araştırma: Göreme Açık Hava Müzesi örneği [A research on perceptions of museum service quality by tourist guides: The case of Göreme Open Air Museum]. Kastamonu Üniversitesi, İktisadi ve İdari Bilimler Fakültesi Dergisi,10, 68-90.

Weitz, M. (1956). The role of theory in aesthetics. The Journal of Aestheticsand Art Criticism, 15(1), 27-35.

Wertz, S. K. (1998). Human nature and art: From Descartes and Hume to Tolstoy. Journal of Aesthetic Education, 32(3), 75-81.

Yıldırım, A., \& Şimşek, H. (2016). Sosyal Bilimlerde Nitel Araştırma Yöntemleri [Qualitative research methods in the social sciences] (10. ed.). Ankara: Seçkin Yayıncllık.

Yılmaz, İ. (2011). Müze ziyaretçilerinin hizmet kalitesi algılamaları: Göreme Açık Hava Müzesi örneği [Service quality perceptions of museum visitors: Göreme Open Air Museum case]. Anatolia: Turizm Araştırmaları Dergisi, 22(2), 183-193.

Yücelt, U. (2000). Marketing museums: An empirical investigation among museum visitors. Journal of Non-profit and Public Sector Marketing, 8(3), 3-13. 